\title{
PR Domain Zinc Finger Protein 2
}

National Cancer Institute

\section{Source}

National Cancer Institute. PR Domain Zinc Finger Protein 2. NCI Thesaurus. Code C143123.

PR domain zinc finger protein 2 (1718 aa, $\sim 189 \mathrm{kDa})$ is encoded by the human PRDM2 gene. This protein is involved in both transcriptional regulation and the methylation of histone $\mathrm{H} 3$. 